These liquid vegetable milks like most other plant-protein products will need fortifying with vitamins and minerals. This fortification should be a fairly simple and inexpensive task, especially in view of the recent dramatic fall in the price of vitamin $B_{\mathbf{1 2}}$. The efficient distribution of vitamins and minerals throughout the different foods will present problems. They should, in my opinion, be added to types of food that might be expected to contain them, for example vitamin $D$ to ghee. Vitamin $B_{12}$ should be added to plant-protein preparations. On the large scale, as in the impulse process, it should be relatively easy. With leaf-protein preparations made in small units by Pirie's methods and with pulses and nuts prepared in the home difficulties will arise and it may be helpful to add vitamin $B_{12}$ to curry powder or other condiments. Recent findings suggest that if sufficient manure is available the traces of vitamin $B_{12}$ in some leaves may be increased so that they will provide the vitamin $B_{12}$ needed for the leaf-protein preparations (Wokes, I96I, unpublished).

In conclusion, my brief examination of India's food problems shows that, even if efforts are concentrated on obtaining an extra 2 million tons of protein annually, there will be many serious difficulties to overcome. Clinical and nutritional research, food technology and control, agriculture, transport, education and economic factors will all have to play a part. Much as we can learn from experience in other countries, India will still confront us with her own special problems, of which ahimsa is not the least important. Nevertheless, we have faith that by facing the challenge firmly we shall find that our efforts have not been wasted.

\title{
REFERENCES
}

Altschul, A. M. (editor) (1958). Processed Plant Protein Foodstuffs. New York: Academic Press Inc. Banerjee, D. K. \& Chatterjea, J. B. (1960). Brit. med. F. ii, 992.

Chayen, I. H. \& Ashworth, D. R. (1953). F. appl. Chem. 3, 529.

Cuthbertson, W. F. J. (I96I). Proc. Nutr. Soc. 20, I22.

Gunther, J. (1947). Inside U.S.A. London: Hamish Hamilton.

Hughes, B. P. (1959). Brit. F. Nutr. 13, 330.

Indian Council of Medical Research: Nutrition Advisory Committee. (1951). Spec. Rep. Ser. Indian med. Res. Coun. no. 20.

Lane, D. E. (1931). Amer. F. Dis. Child. 42, 1384.

Miller, H. (1960). Soybean Dig. October, p. 14.

Payne, W. W., Prankard, T. A. J. \& Wokes, F. (1959). Lancet, ii, 849.

Pirie, N. W. (1947). Food Manuf. 32, 4 I6.

Pirie, N. W. (1959). Brit. Veg. 1, 229.

Rose, W. C. (1957). Nutr. Abstr. Rev. 27, 631.

Russell, J. (1954). World Population and World Food Supplies. London: George Allen and Unwin.

Wokes, F. (1959). Brit. Veg. x, 227.

Wokes, F., Badenoch, J. \& Sinclair, H. M. (1955). Voeding, x6, 590.

Wokes, F., Badenoch, J. \& Sinclair, H. M. (1957). Int. Congr. Nutr. Iv. Paris. Abstr. Pap. p. 219.

\section{The commercial development of a protein-rich food supplement in Nigeria}

\author{
By W. F. J. Cuthbertson, Glaxo Laboratories Ltd, Greenford, Middlesex
}

Nigeria is a large country, which includes several distinct climatic and geological areas and within which live many different peoples, so that it is rarely possible to 
generalize about the country as a whole. Nigeria is also rapidly developing, so that what was true a few years ago may not now be so. For these reasons, among others, a limited part of Nigeria will be considered, i.e. the Western Region, mainly forest and predominantly inhabited by the Yoruba people.

Here, as on the west coast generally, malnutrition, mostly kwashiorkor, is common and child mortality high (Morley, 1959; Gardner \& Gardner, I958; Jonkers, 1958). The figures shown in Table $I$ are for Ilesha and may be taken as typical.

Table 1. Percentage distribution of mortality in children under 5 years in Ilesha, Nigeria, according to its major causes (from Morley, 1959)

(Total infantile mortality $495 /$ rooo live births)

$\begin{array}{lrlr}\text { Diarrhoeal diseases } & \text { I2 } & \text { Pneumonia } & 12 \\ \text { Malnutrition } & \text { I2 } & \text { Malaria } & 8 \\ \text { Pertussis } & 8 & \text { Measles (complications) } & 8 \\ \text { Tuberculosis } & 5 & \text { Smallpox } & 5 \\ \text { Sickle cell disease } & 3 & \text { Other conditions } & 27\end{array}$

The effects of malnutrition and infection are interrelated, in that kwashiorkor is frequently not apparent even at low protein intakes, except when an infection develops; thus, because they exacerbate deficiencies, diarrhoeal diseases, pertussis, measles and pneumonia may be far more serious than amongst well-nourished children. Though precise figures cannot be given, a disproportionately large decrease in mortality might be expected if good nutrition could be established.

The work outlined here was undertaken in an attempt to permit good nutrition. The causes of kwashiorkor were investigated, in particular the methods of rearing children and why they were practised, the nature of the protein foods available and why they were or were not used, and finally the practical steps that might be taken. As a result, a protein-rich food supplement, Amama (Glaxo Laboratories (Nigeria) Ltd), is now being manufactured in Nigeria and sold for use by the public.

\section{Method of rearing children}

Children are fed at the breast for up to $I \frac{1}{2}-2 \frac{1}{2}$ years; from about 6-9 months breast feeding is supplemented with pap, a thin gruel made almost always from maize flour, with occasional pieces of fruit, plantain or yam as solid food. Only when the children are taken off their mothers backs (i.e. when they have both teeth and the ability to toddle), are they allowed 'normal' food; thus from birth up to 2 years of age or more, the children are, apart from the small amount of low-quality protein in the pap, wholly dependent on breast milk for protein. Even after weaning, the children are given only small amounts of protein, particularly animal-protein, foods. This explains the pattern of malnutrition: marasmus or starvation, due to lactational failure, is apparent mainly at $3^{-12}$ months of age and kwashiorkor predominantly between 15 months and 3 years.

20 (2) 4 


\section{Available foods}

Most of the protein and staple foods available are listed in Table 2. The prices are only approximate and vary greatly with the season of the year and locality; the price of all protein foods is high. Fresh milk is unobtainable because dairy cows are not kept.

Table 2. Approximate food costs in Nigeria in pence per lb $(454 \mathrm{~g})$, per 1000 kcal and per $100 \mathrm{~g}$ protein $(N \times 6.25)$

\begin{tabular}{|c|c|c|c|c|c|c|c|}
\hline Food & $\begin{array}{l}\text { per lb } \\
\text { edible } \\
\text { portion }\end{array}$ & $\begin{array}{l}\text { per } \\
\text { I000 } \\
\text { kcal }\end{array}$ & $\begin{array}{l}\text { per } \\
\text { IO0 } \mathrm{g} \\
\text { protein }\end{array}$ & Food & $\begin{array}{l}\text { per lb } \\
\text { edible } \\
\text { portion }\end{array}$ & $\begin{array}{c}\text { per } \\
\text { I } 000 \\
\text { kcal }\end{array}$ & $\begin{array}{c}\text { per } \\
\text { I00 } g \\
\text { protein }\end{array}$ \\
\hline Eggs (12.4) & 78 & 90 & I 35 & Groundnut $(25 \cdot 6)$ & 16 & $6 \cdot 5$ & 14 \\
\hline Fresh meat (I9) & $24-40$ & $29-49$ & $28-46$ & Beans $(22 \cdot 2)$ & $6 \cdot 5-8 \cdot 0$ & $4.0-5.0$ & $6 \cdot 5-8 \cdot 0$ \\
\hline Fresh fish (18) & $24-36$ & $54-82$ & $29-44$ & White flour $(12 \cdot 7)$ & II & 6.6 & 19 \\
\hline Stockfish (42) & 30 & 37 & 16 & Maize (ro) & $4 \cdot 3$ & $2 \cdot 7$ & $9 \cdot 5$ \\
\hline Milk* (26) & $54-76$ & $23-33$ & $46-65$ & Rice $(7 \cdot 1)$ & $8 \cdot 5$ & $5 \cdot 4$ & 26 \\
\hline Corned beef (22) & 48 & 48 & 48 & $\operatorname{Yam}(1 \cdot 9-2 \cdot 4)$ & $2 \cdot 2-3 \cdot 0$ & $4 \cdot 7-6 \cdot 3$ & $25-28$ \\
\hline Amama (5I) & 36 & 24 & I 5 & Plantain (x.8) & 1.8 & 3.5 & 35 \\
\hline Melon seed $(27.5)$ & 22 & 9 & I 8 & Dried cassava (I.5) & $4 \cdot 5$ & 3 & 66 \\
\hline
\end{tabular}

Numbers in parentheses denote the percentage of protein in the food.

Ranges are given for foods of which differently priced types are available in the markets.

* Calculated as dry solids of dried or evaporated milk since fresh milk is unobtainable.

\section{Why the protein foods available are not used}

Practical difficulties. Most kitchens have only the simplest equipment, an earth fireplace, clay, enamel or aluminium pots and bowls, one or two knives and spoons, perhaps a fork, a large pestle and mortar and a grinding stone. With this equipment it is not easy to make purées from some of the available protein sources such as dried or smoked meat; nor can dried milk be used in the way familiar in Europe and N. America because of the problem of cleaning and sterilizing babies' bottles. Mothers can, however, make purées from skinned peas and beans or from eggs and groundnuts or some fish; evaporated and dried milk and Amama are available and may readily be incorporated in the pap for the child.

Traditions and customs. In England, winkles are eaten but snails are not, prawns are a delicacy but even the tastier caterpillars are not consumed, and stewed cat and roast dog would be regarded with horror even though the nutritional value of their meat is equivalent to that of the turkey and pig. In Nigeria also there are food prejudices, but they are of a different kind in that some foods, though normally eaten, may not be consumed in certain circumstances, e.g. during pregnancy or infancy. As an example, beans are thought to cause vomiting and diarrhoea in infants, and for similar reasons infants may not be given any of the readily available protein foods until they are off their mother's backs, have teeth and can walk. Even then it is thought unwise to over-indulge them in these foods for fear that they may not learn self control and may later become greedy ne'er-do-wells. 
There is a Yoruba proverb-'As the dove leaves scraps for the nestling so I leave scraps for my child'. Children are not fed on scraps, but the proverb emphasizes that children are not entitled to the best food. They generally get minute portions of protein foods. For instance, if the dish is fowl in soup, traditionally the men eat the thighs and breast, the women the back and wings and the children the feet, neck and head! These beliefs and traditions are dying out, especially among the educated classes, but are still widely held and must be seriously considered. Children up to the age of 2 or 3 years still often live mainly on starchy foods with the breast as the main protein source. The situation in some ways resembles that in 19 th century English industrial areas, when children were weaned on to paps of cereal flour, though here, because of the readier availability of milk and the higher protein content of the cereals, rickets and scurvy were the dominant deficiency diseases rather than kwashiorkor.

Economic difficulties. According to the Economic Survey of Nigeria (National Economic Council, I959), the mean yearly expenditure on food was about $f_{\mathrm{I}}$ /head. Statistics are not available for the separate regions, but income is greater in the southern part of the country, in which kwashiorkor is more common, than in the northern areas. Whatever the amount of cash available in the Western Region, it is fair to say that undernutrition, due to inability to buy or grow food, is rare, though malnutrition is not. Observations on the quality, neatness and cleanliness of the clothing of people in the streets and at work suggest that poverty is not common and is unlikely to be a major cause of malnutrition; thus calorie deficiency would not be expected to result from persuading the population to use more of the protein foods. On the other hand, most of the population obviously cannot afford to buy as much of the costly protein foods as would be considered normal in Europe and $\mathrm{N}$. America; any proposed new food should therefore be as cheap as possible.

\section{Possible solutions}

In time, good nutrition could, and probably will, be introduced by changing practices that can only result from far-reaching alterations in the pattern of agricultural production, food storage, transport, distribution and consumption which, in turn, depend on vast programmes of education and capital investment and so can only take place slowly. Meanwhile, the problem of malnutrition is pressing and requires an immediate solution.

\footnotetext{
Amama

A product capable of preventing malnutrition should be easy and safe to use, it should keep well and be acceptable to the palate and pocket. It should be a cheap alternative to dried milk in the diet of the weaned or weaning child, but should not be used as a substitute for breast milk. In addition, to decrease transport and handling charges, the product should be as concentrated as is compatible with low cost and high acceptability and for the same reasons its major ingredient should be obtainable within the country.
} 
In Nigeria, groundnut, soya and cottonseed are, or could be, made available for the preparation of a protein-rich food suitable for human consumption. Of these, groundnuts are already produced and processed within the country, and at one mill, Nigerian Oil Mills at Kano, development work had been carried out on the production of a low-fat groundnut flour suitable for human consumption; more recently a Government-owned mill, at Zaria, also began production. At both these mills, oil is expelled at low temperature from kernels that have been husked, skinned and freed from dirt and stones.

Groundnut flour, made at Kano, was selected as the major protein source because of its availability, because work on this and a similar product (Ladell \& Phillips, 1959; De Maeyer \& Vanderborght, 1958) had indicated its value and because it was found to be acceptable as a food in Nigeria (G. Calil, r954-6, private communications). The groundnut flour was mixed with casein, yeast, minerals and vitamins in amounts such that I oz/day, when added to the normal diet of children in the susceptible age group, would be expected to raise the intake of essential amino acids to levels thought satisfactory (FAO: Committee on Protein Requirements, 1957), and also to supply those vitamins in which deficiencies have been observed in Nigeria (Nicol, 1952). Iodine was incorporated in amounts found in laboratory tests (Cuthbertson \& Shearley, r958, unpublished) to overcome the slight goitrogenic action of groundnut flour (Srinivasan, Moudgal \& Sarma, 1957).

It is exceedingly difficult to carry out adequate tests on the value of a protein supplement or its acceptability in Nigeria, if only because of the shortage of doctors and nurses and of the required facilities, but batches of Amama, made in England, were widely distributed to hospitals and clinics in Nigeria in order to gain impressions from the medical staff of its efficacy in the prevention of malnutrition, its acceptability and its ease of use by the mothers for their children. It was found that the mothers could use and would buy Amama and that it did not lead to complaint even when given in much larger amounts (up to 4 oz/day) than would normally be recommended. Because Amama was a new product, it was not subject to the prejudices held about most other protein foods.

Practical tests were carried out at Ilesha (Morley, 1959). In one trial, children from consecutive births in a typical Western Region village were allotted, when 9 months old, to one or other of two groups. The mothers in one group were given $\frac{1}{2} \mathrm{lb}$ of Amama per week, the others none. After 3 months, the Amama was withdrawn from the one group but then given to the other. The results of this test showed that the Amama-supplemented group grew faster $(\mathrm{I} \cdot \mathrm{I} \mathrm{kg})$ between the ages of 9 and $\mathrm{I} 2$ months than the controls $(0.45 \mathrm{~kg})$ and again the Amama group grew faster $(0.86 \mathrm{~kg})$ than the controls $(0.63 \mathrm{~kg})$ between the ages of 12 and 15 months. The effects of Amama and milk-powder supplements ( $\mathrm{I}$ oz/day) were also compared in groups of children who had failed to gain weight over the preceding 3 months in spite of normal medical attention. In this test, both groups put on approximately $2 \mathrm{~kg}$ during the 6-month treatment period, thus showing that in this respect Amama did not differ significantly from skim-milk powder. Simultaneously work was undertaken on methods of packaging to prevent spoilage from moisture and insects and on the 
stability of the packed product under a variety of climatic conditions. A large pack, though cheaper per oz of contents, would be dearer per pack than a small one and after opening would be exposed longer to moisture and insect attack. An 8 oz pack was therefore adopted, as a reasonable compromise, for the product to be manufactured in a new factory built at Apapa near Lagos.

\section{Advertising and education}

The manufacture and distribution of a new food to wholesalers and retailers is not enough to ensure its use; an advertising and educational programme is essential so that the public can become aware of its availability and how to use it. This raises a series of problems in communication. Advertisements and articles in the Press serve this purpose well in England, but in Nigeria the Press is not so effective. The combined circulation of the three major daily and three major weekly papers only total about 10/1000 of the population, a figure exceeded by each of thirteen daily and weekly papers in the U.K. which have a combined circulation of about 800/1000.

The Press, however, cannot be neglected, because it is read by the educated classes from whom the rest of the population takes a lead. The value of leaflets and posters may be limited because of the low literacy rate; in one hospital, in a large town, only $18 \%$ of mothers had been to school. These figures may not be typical, but do indicate the problem. Wireless and television can be employed and so can the cinema, but again the sets are much fewer and audiences much smaller, absolutely and proportionately, than in England. Mobile vans with demonstrators are useful but costly.

There are big language difficulties because in Nigeria over 200 languages, belonging to three different groups, are spoken. Though the educated can speak English and possibly about $50 \%$ of the population can speak one or other of the three major languages, Hausa, Yoruba and Ibo, the language barrier is still formidable. Other handicaps exist; in England there is some knowledge of nutrition, in that vitamins, proteins and calories are household words, but it is not so in Nigeria. Last but not least, in the U.K. there is a wealth of statistical information, knowledge of traditions and of public reactions available for deciding the allocation of money for advertising and educational campaigns. In Nigeria statistics are less complete, knowledge of attitudes and traditions of the many varied peoples is limited, and reliable methods of assessing public reaction have not been developed, so that there are considerable difficulties in deciding how best to spend limited funds available for education and advertising, to whom the information should be addressed and how to assess the success of any programme.

This report outlines the development of Amama as a practical step to good nutrition, first in West Africa and now in East Africa also, a development due not to one or two individuals, but to the enthusiastic co-operation of many, especially doctors and nurses, in the countries concerned and also to the co-operative efforts of several different departments within Glaxo Laboratories Ltd, at home and abroad. 
De Maeyer, E. M. \& Vanderborght, H. (1958). F. Nutr. 65, 335.

FAO: Committee on Protein Requirements. (1957). FAO nutr. Stud. no. 16.

Gardner, R. F. R. \& Gardner, E. S. (1958). F. Obstet. Gynaec., Brit. Emp. 45, 749.

Jonkers, A. H. (1958). Trop. Geog. Med. 10, 61.

Ladell, W. S. S. \& Phillips, P. G. (1959). F. trop. Med. Hyg. 62, 229.

Morley, D. C. (1959). Read at Congr. Ass. int. Pédiat. Ix. Montreal. (Unpublished.)

National Economic Council. (1959). Economic Survey of Nigeria. Lagos: Federal Government Printer.

Nicol, B. (1952). Brit. Y. Nutr. 6, 34.

Srinivasan, V., Moudgal, N. R. \& Sarma, P. S. (1957). f. Nutr. 6r, 87.

\section{Factors affecting development of food science and technology and food research in Pakistan}

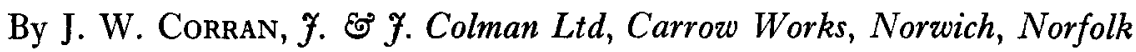

Experience gained during a recent assignment in Pakistan on behalf of the Food and Agriculture Organization of the United Nations forms the background to this paper. Several years ago the Pakistan Government decided to set up a Council of Scientific and Industrial Research under the Ministry of Industries. Included in the plans was provision for the setting up, within the Council, of an organization for food research and its application to the promotion of the food industries of that country. The reports of this assignment (Corran, 1959), and a previous one (Fidler, 1957), submitted to FAO, contain recommendations which form the basis of this contribution.

Pakistan, with a total population of about 93 million, covers an area of about 370000 sq. miles. It is divided into two wings, West and East, rooo miles apart. West Pakistan is bounded by the Mekran Coast in the west, the Hindu Kush mountains in the north, and the western frontier of India in the east. East Pakistan, formerly the eastern part of Bengal, is bounded on the south by the Bay of Bengal, and is enclosed on its east, west and north borders by India. Whereas the area of West Pakistan covers 317000 sq. miles with a population density of rog/sq. mile, that of East Pakistan is 53000 sq. miles with a population density of $777 / \mathrm{sq}$. mile. Thus, the population density of East Pakistan is seven times that of West Pakistan. They are essentially Muslim communities.

The southern half of West Pakistan is mainly desert, although wide areas around the river Indus have been brought into cultivation. The northern half, embracing the West Punjab and N.W. Frontier Province, is well irrigated by the five rivers of Pakistan, with a connecting series of canals and irrigation ditches. In consequence, most of the Punjab is highly productive of agricultural products (grain, fruits, sugarcane, tobacco, cotton, jute) and maintains a substantial population of domestic animals (cows, buffaloes, goats, sheep). In general, where water is available, as in the Peshawar Valley of N.W. Frontier Province, in the Quetta Valley of Baluchistan and in the Punjab, crop and fruit yields can be high. Where water is not available the 